Article

\title{
Activity of Bacteriophage and Complex Tannins against Biofilm-Forming Shiga Toxin-Producing Escherichia coli from Canada and South Africa
}

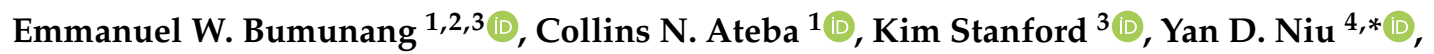 \\ Y. Wang ${ }^{2}$ and Tim A. McAllister ${ }^{2, *(D)}$ \\ 1 Department of Microbiology, Faculty of Natural and Agricultural Sciences, Mafikeng Campus," \\ North-West University, Private Bag X2046, Mmabatho 2735, South Africa; bumunang@gmail.com (E.W.B.); \\ Collins.Ateba@nwu.ac.za (C.N.A.) \\ 2 Agriculture and Agri-Food Canada, Lethbridge Research and Development Centre, \\ Lethbridge, AB T1J 4B1, Canada; yuxi.wang@canada.ca \\ 3 Alberta Agriculture and Forestry, Lethbridge, AB T1J 4V6, Canada; kim.stanford@gov.ab.ca \\ 4 Department of Ecosystem and Public Health, Faculty of Veterinary Medicine, University of Calgary, \\ Calgary, AB T2N 1N4, Canada \\ * Correspondence: dongyan.niu@ucalgary.ca (Y.D.N.); tim.mcallister@canada.ca (T.A.M.); \\ Tel.: +1-403-210-3847 (Y.D.N.); +1-403-317-2240 (T.A.M.)
}

Received: 18 April 2020; Accepted: 13 May 2020; Published: 15 May 2020

\begin{abstract}
Bacteriophages, natural killers of bacteria, and plant secondary metabolites, such as condensed tannins, are potential agents for the control of foodborne pathogens. The first objective of this study evaluated the efficacy of a bacteriophage SA21RB in reducing pre-formed biofilms on stainless-steel produced by two Shiga toxin-producing Escherichia coli (STEC) strains, one from South Africa and the other from Canada. The second objective examined the anti-bacterial and anti-biofilm activity of condensed tannin (CT) from purple prairie clover and phlorotannins (PT) from brown seaweed against these strains. For 24-h-old biofilms, (O113:H21; $6.2 \log _{10}$ colony-forming units per square centimeter $\left(\mathrm{CFU} / \mathrm{cm}^{2}\right)$ and $\left.\mathrm{O} 154: \mathrm{H} 10 ; 5.4 \log _{10} \mathrm{CFU} / \mathrm{cm}^{2}\right), 3 \mathrm{~h}$ of exposure to phage $\left(10^{13}\right.$ plaque-forming units per milliliter $(\mathrm{PFU} / \mathrm{mL}))$ reduced $(p \leq 0.05)$ the number of viable cells attached to stainless-steel coupons by 2.5 and $2.1 \log _{10} \mathrm{CFU} / \mathrm{cm}^{2}$ for O113:H21 and O154:H10, respectively. However, as biofilms matured, the ability of phage to control biofilm formation declined. In biofilms formed for $72 \mathrm{~h}\left(\mathrm{O} 113: \mathrm{H} 21 ; 5.4 \log _{10} \mathrm{CFU} / \mathrm{cm}^{2}\right.$ and $\left.\mathrm{O} 154: \mathrm{H} 10 ; 7 \log _{10} \mathrm{CFU} / \mathrm{cm}^{2}\right)$, reductions after the same duration of phage treatment were only 0.9 and $1.3 \log _{10} \mathrm{CFU} / \mathrm{cm}^{2}$ for O113:H21 and O154:H10, respectively. Initial screening of CT and PT for anti-bacterial activity by a microplate assay indicated that both STEC strains were less sensitive $(p \leq 0.05)$ to CT than PT over a concentration range of $25-400 \mu \mathrm{g} / \mathrm{mL}$. Based on the lower activity of CT $(25-400 \mu \mathrm{g} / \mathrm{mL})$, they were not further examined. Accordingly, PT $(50 \mu \mathrm{g} / \mathrm{mL})$ inhibited $(p \leq 0.05)$ biofilm formation for up to $24 \mathrm{~h}$ of incubation at $22{ }^{\circ} \mathrm{C}$, but this inhibition progressively declined over $72 \mathrm{~h}$ for both O154:H10 and O113:H21. Scanning electron microscopy revealed that both SA21RB and PT eliminated $24 \mathrm{~h}$ biofilms, but that both strains were able to adhere and form biofilms on stainless-steel coupons at longer incubation times. These findings revealed that phage SA21RB is more effective at disrupting 24 than $72 \mathrm{~h}$ biofilms and that PT were able to inhibit biofilm formation of both E. coli O154:H10 and O113:H21 for up to $24 \mathrm{~h}$.
\end{abstract}

Keywords: biofilms; bacteriophage; condensed tannin; phlorotannins; Shiga toxin-producing Escherichia coli; stainless-steel coupon 


\section{Introduction}

Food safety is a top priority for the food-processing industry given that foodborne infections are a great burden to public health and also cause huge economic losses [1]. Food products contaminated with Shiga toxin-producing Escherichia coli (STEC) have caused serious outbreaks in humans for decades [2-4]. For example, STEC serotype O113:H21, which has been associated with human illness [5,6] and O154:H10, which has the ability to colonize and form biofilms on food contact surfaces under different environmental conditions, also poses a health risk $[7,8]$. The persistence of STEC biofilms on food contact surfaces is a contributing factor to the contamination of food products $[9,10]$.

The potential of biofilms to resist antimicrobial treatment is due to a protective outer layer, the exopolysaccharide matrix and the multiple bacterial layers of biofilms which protect embedded cells against disinfectants and other antimicrobial agents [11,12]. The ability to chelate cationic antimicrobials as a result of the presence of extracellular DNA within the biofilm matrix [13] and to concentrate enzymes such as beta-lactamases, increases the resistance of biofilms to antimicrobials [14]. Additionally, cells within the biofilm enter a state of metabolic dormancy which further reduces the effectiveness of antimicrobials [15]. Furthermore, close proximity of cells within the biofilm can promote the horizontal transfer of genes that confer resistance to antimicrobials [11].

Controlling biofilms is a vital aspect of ensuring food safety within food-processing environments [16] and one of the prime reasons as to why food contact surfaces are routinely sanitized [17]. However, there are safety concerns surrounding the use of antimicrobials in controlling biofilms as it can promote resistance [18] as well as introduce antimicrobial residues into food [19]. Therefore, there is a need for alternative agents such as bacteriophages, which are natural predators of bacteria [20].

Bacteriophages (phages) are ubiquitous in nature, host-specific, non-toxic and self-replicating, making them potential alternatives to traditional antimicrobials [21]. Phages could disrupt biofilms through their ability to infect and lyse bacteria. In addition, phages that possess genes coding for exopolysaccharide depolymerases are considered superior anti-biofilm agents as these enzymes can degrade the exopolysaccharide matrix that protects bacteria within biofilms [22,23]. Phages have been applied against bacterial biofilms formed on a variety of different surfaces [24-26] and have shown promise as an effective control measure $[27,28]$.

Additionally, the search for novel antimicrobial agents that prevent the adhesion of bacterial cells to surfaces could be instrumental in inhibiting biofilm formation $[29,30]$. Tannins are polyphenolic compounds with demonstrated anti-bacterial [31-33] and anti-biofilm activity [34-36]. Although the affinity of tannins for proteins has been well documented [37,38], the precise mechanisms whereby they inhibit STEC and disrupt biofilms is poorly understood. Possible mechanisms include the binding of tannins to bacterial outer membrane proteins and inhibition of cell wall and nucleic acid synthesis $[29,33]$.

This study assessed alternative approaches to controlling biofilms formed by O154:H10 and O113:H21 STEC on stainless-steel coupons. Preliminary investigations found that tannins formed complexes with phage, eliminating their biological activity. As a result, the activity of phage and tannins against biofilms was assessed separately. The first objective was to evaluate the efficacy of a newly isolated depolymerase-secreting phage, SA21RB [39], in removing pre-formed biofilms of these two strains. The second objective was to investigate the activity of condensed tannins from purple prairie clover (Dalea purpurea) and phlorotannins from brown seaweed (Ascophyllum nodosum) against the formation of biofilms on the surface of stainless-steel coupons. 


\section{Results}

\subsection{Experiment 1}

2.1.1. One-Step Growth Curve, and Susceptibility of O154:H10 and O113:H21 to Phage SA21RB

The one-step growth curve indicated that phage SA21RB had a latent period of $40 \mathrm{~min}$ and a burst size of 43 phages per infected cell (Figure 1). Based on visual observation of a microplate phage virulence assay, both strains (O154:H10 and O113:H21) were susceptible to SA21RB (Table 1).

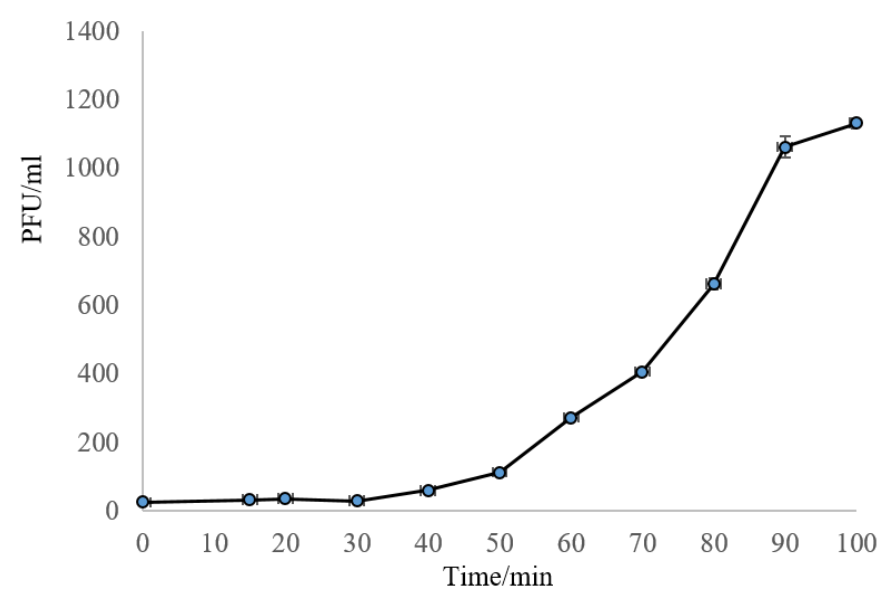

Figure 1. One-step growth curve of phage SA21RB.

Table 1. Lytic effect of phage SA21RB on E. coli O154:H10 and E. coli O113:H21.

\begin{tabular}{ccc}
\hline Phage Titer (Plaque-Forming Units per Milliliter (PFU/mL)) & O154:H10 & O113:H21 \\
\hline $1 \times 10^{13}$ & $\mathrm{C}$ & $\mathrm{C}$ \\
$1 \times 10^{12}$ & $\mathrm{SC}$ & $\mathrm{C}$ \\
$1 \times 10^{11}$ & $\mathrm{~T}$ & $\mathrm{C}$ \\
$1 \times 10^{10}$ & $\mathrm{~T}$ & $\mathrm{SC}$ \\
$1 \times 10^{9}$ & $\mathrm{~T}$ & $\mathrm{~T}$ \\
\hline
\end{tabular}

C, clear (complete lysis); SC, slightly clear; T, turbid (no lysis).

2.1.2. Treatment of Biofilms with Bacteriophage SA21RB Plate Count and Scanning Electron Microscopy (SEM)

Removal of biofilms following phage $\left(10^{13}\right.$ plaque-forming units per milliliter $\left.(\mathrm{PFU} / \mathrm{mL})\right)$ treatment was assessed by enumerating viable cells on stainless-steel after $3 \mathrm{~h}$ of treatment at $22{ }^{\circ} \mathrm{C}$, as compared to untreated controls. Results indicated that phage treatment of O154:H10 and O113:H21 reduced $(p \leq 0.05)$ biofilm formation after $24 \mathrm{~h}$, as compared to untreated biofilms (5.4 and $6.2 \log _{10}$ colony-forming units per square centimeter $\left(\mathrm{CFU} / \mathrm{cm}^{2}\right)$; Figure 2). Interestingly, the effectiveness whereby phage reduced cell viability decreased $(p \leq 0.05)$ for both $E$. coli strains as biofilms aged. For O113:H21 and O154:H10 respectively, the reductions as a result of exposure to phage were 2.5 and $2.1 \log _{10} \mathrm{CFU} / \mathrm{cm}^{2}$ for $24 \mathrm{~h}$ biofilms as compared to 0.9 and $1.3 \log _{10} \mathrm{CFU} / \mathrm{cm}^{2}$ for biofilms that had formed for $72 \mathrm{~h}$ (Figure 2). 

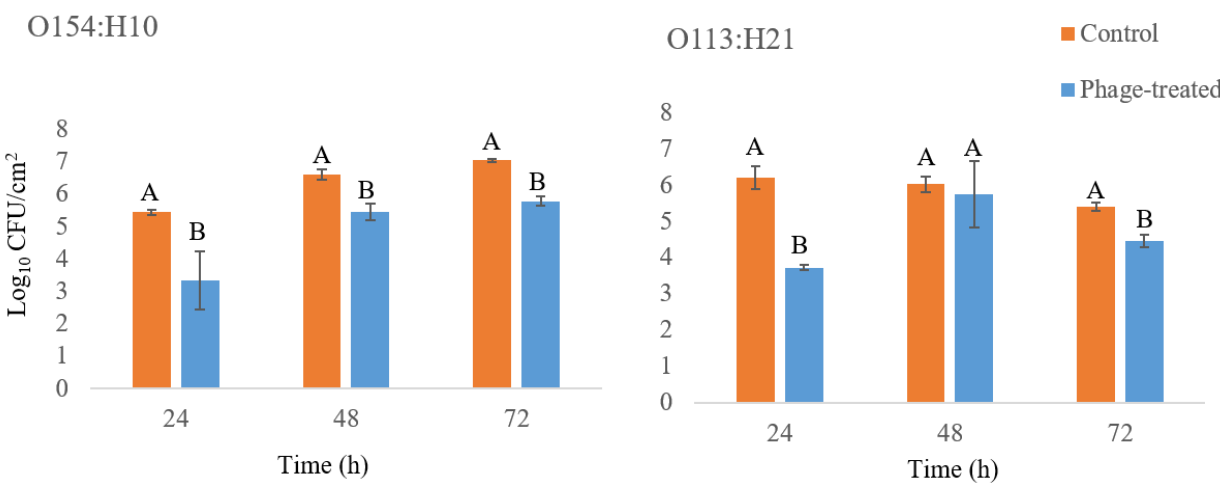

Figure 2. The number of surviving E. coli O154:H10 and O113:H21 cells $\left(\log _{10} \mathrm{CFU} / \mathrm{cm}^{2}\right)$ associated with biofilms treated or untreated with phage SA21RB $\left(10^{13} \mathrm{PFU} / \mathrm{mL}\right)$. Different uppercase letters denote differences at $p<0.05$ among phage-treated and control coupons. Bars $=$ standard error $(n=3)$.

Phage-treated and untreated biofilms were examined by transmission electron microscopy. Results confirmed that phage were more effective against biofilms that formed over $24 \mathrm{~h}$ as compared to those that formed over $72 \mathrm{~h}$ (Figure 3). Evidence of biofilm cell disruption could be seen in O113:H21, which displayed both lysed and morphologically normal rod-shaped cells (Figure 3).

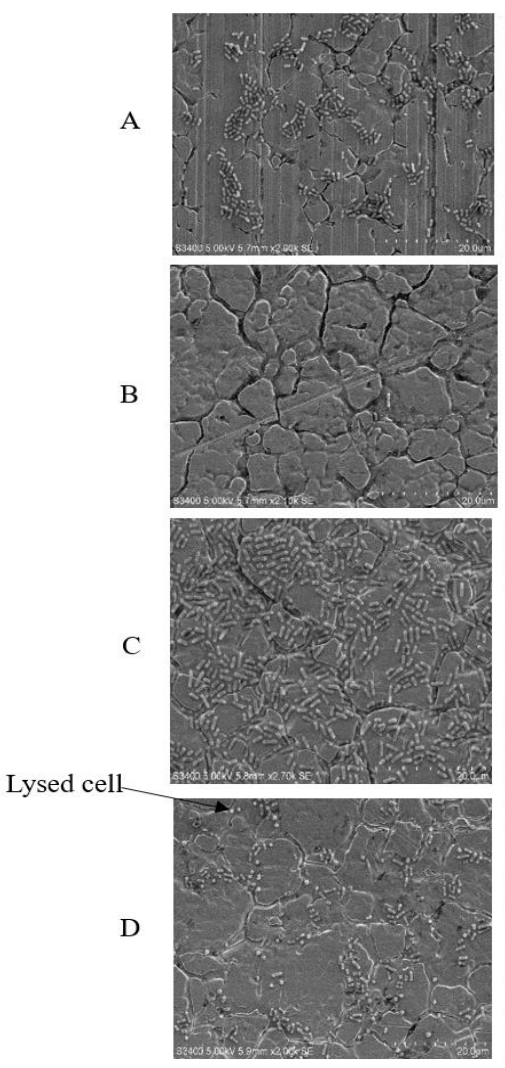

$24 \mathrm{~h}$
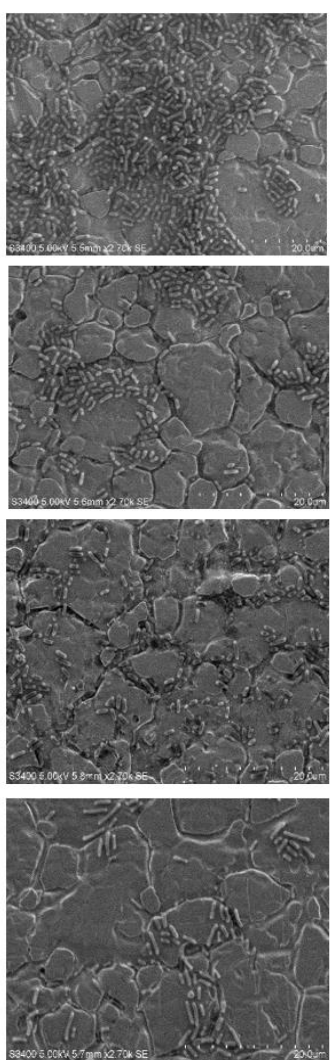

$48 \mathrm{~h}$
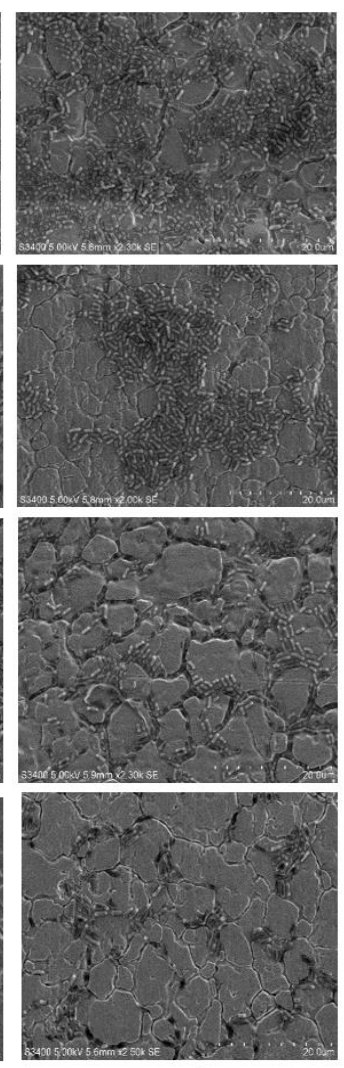

$72 \mathrm{~h}$

Figure 3. Scanning electron microscopy images for phage-treated $\left(10^{13} \mathrm{PFU} / \mathrm{mL}\right)$ biofilms after 24 , 48 and $72 \mathrm{~h}$ of incubation. E. coli O154:H10 untreated controls (A) and phage-treated (B), and E. coli O113:H21 untreated controls (C) and phage-treated (D). Bar $=20 \mu \mathrm{m}$. 


\subsection{Experiment 2}

2.2.1. Effects of Condensed Tannins (CT) and Phlorotannins (PT) on Growth of O154:H10 and O113:H21

Inhibitory effects $(p \leq 0.05)$ of CT and PT on growth of O154:H10 and O113:H21 after $24 \mathrm{~h}$ of incubation at $22{ }^{\circ} \mathrm{C}$ were observed (Figure 4). PT had a dose-independent action, as similar numbers of viable cells were observed regardless of increasing tannin concentrations (25-400 $\mu \mathrm{g} / \mathrm{mL})$. In contrast, CT showed a dose-dependent effect in which the higher the tannin concentration, the greater the inhibition (Figure 4). Overall, O154:H10 and O113:H21 were more sensitive ( $p \leq 0.05)$ to PT than $\mathrm{CT}$, and O113:H21 was more sensitive $(p \leq 0.05)$ to PT than was O154:H10 (Figure 4). CT at the highest concentration $(400 \mu \mathrm{g} / \mathrm{mL})$ had a minimal inhibitory effect $(p \leq 0.05)$, as compared to PT at $25-400 \mu \mathrm{g} / \mathrm{mL}$ (Figure 4). Based on this observation, the ability of PT (50 $\mu \mathrm{g} / \mathrm{mL})$ to inhibit biofilms was investigated and CT were not examined further.

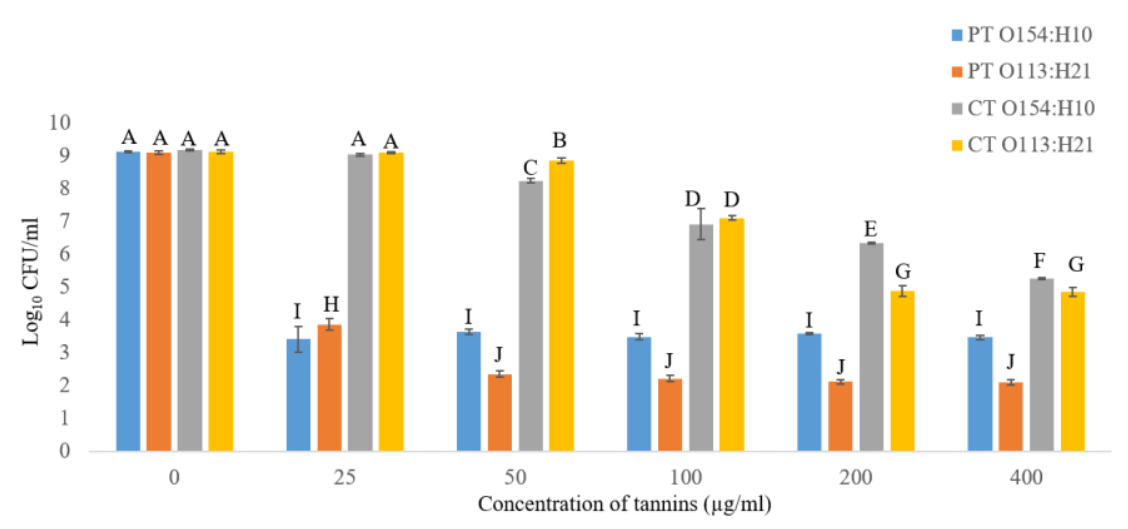

Figure 4. The anti-bacterial effect of condensed tannins (CT) and phlorotannins (PT) at five concentrations (25-400 $\mu \mathrm{g} / \mathrm{mL})$ on E. coli O154:H10 and O113:H21. Different uppercase letters denote differences at $p<0.05$ among condensed tannins and phlorotannins. Bars $=$ standard error $(n=3)$.

\subsubsection{Anti-Biofilm Activity of Phlorotannins}

Biofilm formation was inhibited ( $p \leq 0.05)$ by $50 \mu \mathrm{g} / \mathrm{mL}$ of PT for up to $24 \mathrm{~h}$ of incubation for O154:H10 and O113:H21 in relation to untreated controls (Figure 5). Similarly, compared to controls (8.7 and $\left.8.9 \log _{10} \mathrm{CFU} / \mathrm{mL}\right)$, growth of planktonic cells of O154:H10 and O113:H21 was inhibited $(p \leq 0.05)$ by PT (5.2 and $5.9 \log _{10} \mathrm{CFU} / \mathrm{mL}$ ) after $24 \mathrm{~h}$ of incubation (Figure 5). Conversely, both E. coli strains overcame the inhibitory effects of PT after $72 \mathrm{~h}$ of incubation, as biofilm cell concentrations $(6.5$ and $\left.6.4 \log \mathrm{CFU} / \mathrm{cm}^{2}\right)$ were, by that time, similar to those of untreated samples $\left(6.8\right.$ and $6.2 \log \mathrm{CFU} / \mathrm{cm}^{2}$; Figure 5). Likewise, after 48 and $72 \mathrm{~h}$ of incubation, growth of planktonic cells from PT-bacteria mixture was similar to untreated controls for both O154:H10 and O113:H21 (Figure 5). 
O154:H10 Biofilm cells

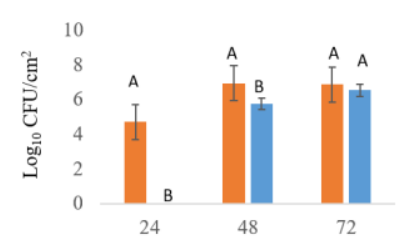

O113:H21 Biofilm cells

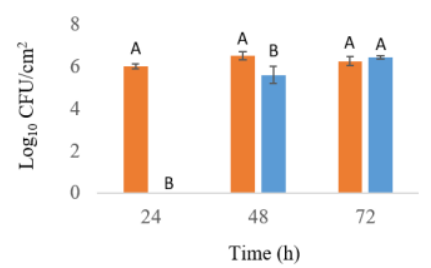

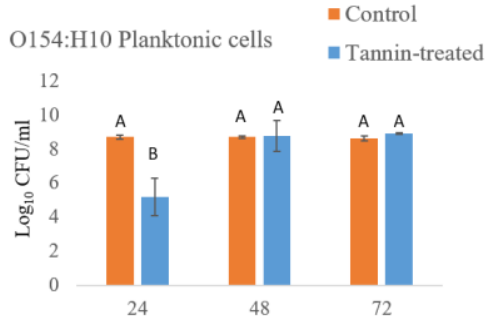

O113:H21 Planktonic cells

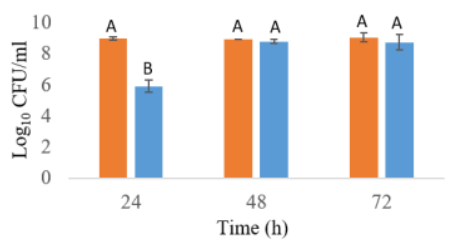

Figure 5. Effect of phlorotannins $(50 \mu \mathrm{g} / \mathrm{mL})$ on E. coli O154:H10 and E. coli O113:H21 biofilm formation and planktonic cell growth after 24, 48 and $72 \mathrm{~h}$ of exposure. Different uppercase letters denote differences at $p<0.05$ among phlorotannin-exposed and controls. Bars $=$ standard error $(n=3)$.

\subsubsection{SEM Analysis}

Compared to controls, no biofilms were found on coupons in PT-bacteria mixture after $24 \mathrm{~h}$ of incubation at $22{ }^{\circ} \mathrm{C}$ (Figure 6). Nonetheless, O154:H10 and O113:H21 cells were able to grow, adhere and form biofilms on stainless-steel at 48 and $72 \mathrm{~h}$ in the presence of PT (Figure 6). No difference in cell morphology was observed with biofilms in PT-bacteria mixture as compared to control biofilms (Figure 6).

A
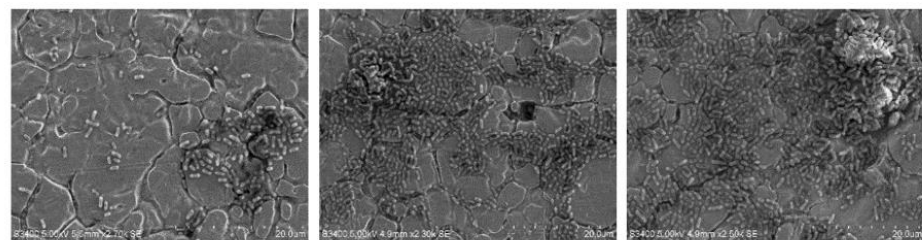

B
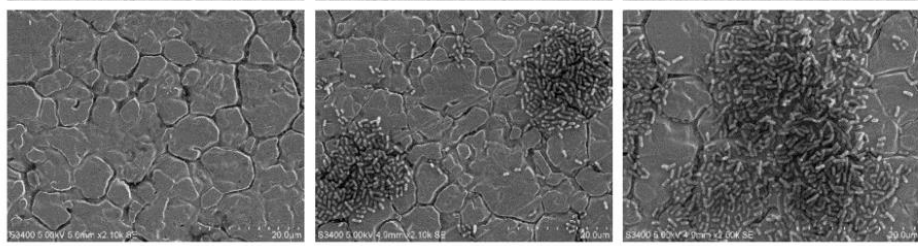

C
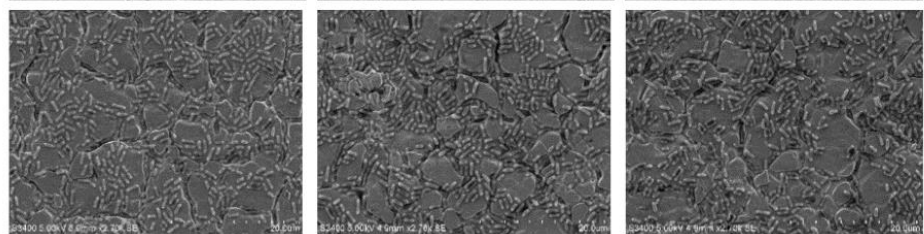

D
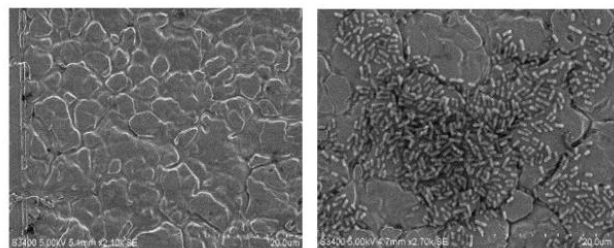

$48 \mathrm{~h}$

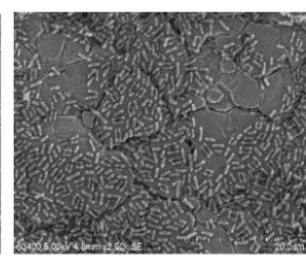

$24 \mathrm{~h}$

$72 \mathrm{~h}$

Figure 6. Scanning electron microscopy images for phlorotannins-exposed ( $50 \mu \mathrm{g} / \mathrm{mL})$ coupons after 24, 48 and $72 \mathrm{~h}$ of incubation. E. coli O154:H10 untreated controls (A) and phlorotannin-exposed (B), and E. coli O113:H21 untreated controls (C) and phlorotannin-exposed (D). Bar $=20 \mu \mathrm{m}$. 


\subsection{Experiment 3}

Sensitivity of Phage SA21RB to Phlorotannins

The incubation of phage SA21RB and PT for $3 \mathrm{~h}$ at $22^{\circ} \mathrm{C}$ decreased the viability of phage titer by 9 $\log _{10}$ (Table 2; Figure S1 in the Supplementary Material).

Table 2. Effect of phlorotannins $(50 \mu \mathrm{g} / \mathrm{mL})$ on the number of viable phage after $3 \mathrm{~h}$ of exposure at $22^{\circ} \mathrm{C}$.

\begin{tabular}{ccc}
\hline Dilution & \multicolumn{2}{c}{ Phage Titer $($ PFU/mL) } \\
\hline & Phage Only & Phage-PT \\
\hline 1 & TNTC & $1.5 \times 10^{3}$ \\
8 & TNTC & 0 \\
9 & TNTC & 0 \\
10 & $8.7 \times 10^{12}$ & 0 \\
\hline \multicolumn{3}{c}{ TNTC, too numerous to count. }
\end{tabular}

\section{Discussion}

\subsection{Biofilm Removal Using Phage SA21BR}

This study evaluated the effectiveness of phage SA21RB and phlorotannins against biofilms formed on stainless-steel by STEC strains O154:H10 and O113:H21 STEC from South Africa and Canada, respectively. Bacteria within biofilms are more resistant to disinfectants and other antimicrobials than those that are in a planktonic form [40,41]. Therefore, removal or prevention of biofilm formation would help curb contamination and dissemination of biofilm-related infectious agents within the food industry [42]. The first part of this study focused on phage-biofilm interactions. Phage SA21RB was selected for this study because of its lytic potential, high burst size and de-polymerase activity [39].

The findings indicated that the susceptibility of O154:H10 and O113:H21 E. coli planktonic cells to phage SA21RB is isolate-dependent. Similarly, variable susceptibility of different bacterial strains to the same phage has been reported $[43,44]$ and is attributed to differences in receptors on the surface of the bacterial cell [45]. Phage treatment demonstrated that biofilms of O154:H10 and O113:H21 were susceptible to phage SA21RB and corroborates previous studies which demonstrate that biofilms of different bacterial strains on various food production surfaces are susceptible to phage. For example, a lytic bacteriophage (BPECO 19) was shown to reduce E. coli O157:H7 biofilms by 3 $\log _{10}$ on stainless-steel [46]. Biofilms of Listeria monocytogenes on stainless-steel were reduced by 3.5 to $5.4 \mathrm{log} / \mathrm{cm}^{2}$ using bacteriophage P100 [47]. Also, phage $\varphi$ IBB-PF7A was able to reduce Pseudomonas fluorescens biofilms on stainless-steel coupons by 3 to $5 \log _{10}$ after $4 \mathrm{~h}$ of phage exposure [48]. However, as in our study, biofilms were not completely removed from stainless-steel coupons as a result of exposure to phage. Factors such as temperature [49], cell density [50], diffusion barrier [51] and bacterial growth stage [52] can affect the extent that biofilm cells are lysed by phages. In this study, $3 \mathrm{~h}$ of exposure to phage SA21RB resulted in partial removal of biofilms at $22{ }^{\circ} \mathrm{C}$. This treatment duration was selected given that phage SA21RB showed a latent time of $40 \mathrm{~min}$, and also to reduce the likelihood of phage-resistant bacterial strains emerging as a result of longer exposure periods [48]. Effectiveness of the phage against biofilms formed by both strains (O154:H10 and O113:H21) decreased with biofilm aging. A greater log reduction in cells associated with $24 \mathrm{~h}$ as compared to $72 \mathrm{~h}$ biofilms could reflect the greater metabolic activity of cells in younger biofilms, increasing their susceptibility to phage. In contrast, cells in more mature biofilms are less metabolically active and less susceptible to phage infection given their embedded location within the biofilm matrix [53]. Another possible explanation, reviewed by Harper, Parracho, Walker, Sharp, Hughes, Werthén, Lehman and Morales [54], suggested that phage can infect less metabolically active cells but cannot replicate, as the expression of the lytic gene is suppressed in cells that are in stasis as compared to those that are actively growing. Based on our data, a decrease in the rate of biofilm removal by phage SA21RB can be attributed to the metabolic 
state of the biofilm cells and not to the number of cells on the coupon, as numbers were similar at 24 and $72 \mathrm{~h}$. Consequently, phage SA21RB was most likely to be effective if it was used to control newly formed biofilms.

Some phage possess enzymes that can degrade the exopolysaccharide (EPS) components of the biofilm matrix [55]. Phage SA21RB showed de-polymerase activity against O154:H10 planktonic cells [39], suggesting that the failure of the phage to completely remove the biofilm is unlikely due to its inability to penetrate the EPS barrier. Therefore, this observation supports the suggestion that complete eradication of biofilms using bacteriophage is unlikely [27]. However, the promising effects of phage in reducing biofilms on stainless-steel suggest that they could be used at some point after the application of disinfectants so as to target recently formed biofilms.

\subsection{Biofilm Prevention Using Phlorotannins}

Incomplete eradication of biofilms of these strains using phage SA21RB motivated us to explore tannins for their anti-biofilm activity. The anti-bacterial activity of condensed tannins from purple prairie clover and phlorotannins from brown seaweed, against planktonic O157 and non-O157 E. coli, has been examined previously [31]. Wang et al. [31] indicated that PT had a greater effect against non-O157 E. coli than terrestrial CT. Similarly, this work found that PT have greater activity against planktonic cells of O154:H10 and O113:H21 than CT. Greater anti-bacterial activity of PT has been attributed to their high degree of polymerization [56,57]. In addition, PT readily forms complexes with proteins through free hydroxyl group [58], and have more of these reactive sites than CT [31]. Variation in the nature of outer membrane proteins may also account for the differences in the sensitivity of O113:H21 and O154:H10 to PT, an observation that corroborates the findings of others [31,56]. The anti-bacterial activity of tannins is attributed to several mechanisms, including its ability to complex with the outer membrane of bacteria and the sequestration of minerals required for bacterial growth [58]. Therefore, it was assumed that the ability of PT to inhibit planktonic growth of O154:H10 and O113:H21 could stop biofilm formation.

Our results indicate that PT could stop the initiation of biofilms by planktonic O113:H21 and O154:H10 over a period of up to $24 \mathrm{~h}$. Similar results were reported by Trentin et al. [35], who found that CT from Anadenanthera colubrine, Commiphora leptophloeos and hydrolyzable tannins from Myracrodruon urundeuva inhibited biofilm formation by Pseudomonas aeruginosa on polystyrene over $24 \mathrm{~h}$. Also, the report of da Silva et al. [59] indicates that polyphenolic compounds in medicinal plants from Brazil have an anti-biofilm effect against Staphylococcus epidermidis in polystyrene 96-well microtiter plates over $24 \mathrm{~h}$.

The mechanisms responsible for the effect of plant polyphenols on biofilm formation are not fully understood. Some possibilities include inhibition of cell growth and exopolysaccharide synthesis, anti-adhesivity and attachment activities and inhibition of quorum sensing [29,60]. The former supports the explanation as to why no biofilm cells were obtained after $24 \mathrm{~h}$ in this study and can be attributed to minimal planktonic bacterial growth in the presence of PT. Additionally, an increase in the planktonic cell number with incubation $>24 \mathrm{~h}$ corroborates the biofilm results after $48 \mathrm{~h}$ in the presence of PT, showing growth above the minimum range $\left(\geq 5 \log \mathrm{CFU} / \mathrm{cm}^{2}\right)$ indicative of biofilm formation [61]. Therefore, another explanation could be that PT inhibit, but do not completely stop, the growth of STEC. As STEC continue to grow, they eventually produce enough cells to inactivate the PT, enabling biofilms to form at later incubation times. Contrary to this hypothesis, Trentin et al. [35] found that tannins inhibited biofilm formation without inhibiting bacterial growth. For example, da Silva et al. [59] observed that plant extracts of Bauhinia acuruana, Commiphora leptophloeos, Bauhinia acuruana and Pityrocarpa moniliformis prevented biofilm formation by Staphylococcus epidermidis on glass and polystyrene without inhibiting planktonic cell growth. These reports propose that the anti-adhesive properties of the plant extracts are responsible for their anti-biofilm activity. A previous study has demonstrated that the rate of inactivation of tannin is higher at 20 or $37^{\circ} \mathrm{C}$ than at $0{ }^{\circ} \mathrm{C}$ [62]. Also, PT 
contain many hydroxyl groups and are highly oxidized when exposed to air [63,64]. The loss of activity in PT in this study could be a result of oxidation of these groups through exposure to air at $22{ }^{\circ} \mathrm{C}$.

Based on SEM results, no biofilm cells were observed after $24 \mathrm{~h}$ of exposure to PT, an observation that was confirmed by plate counts of PT-exposed cells. Nevertheless, attached bacterial cells were enumerated after 48 and $72 \mathrm{~h}$ and exhibited a normal rod-shaped morphology in the presence of PT. Another possible explanation for bacterial attachment and subsequent biofilm formation could be that PT did not inhibit or interact with extracellular structures involved in biofilm formation, such as the fimbriae and curli [65]. Also, the normal rod-shaped morphology suggests there was no direct interaction of PT with the bacterial cell membrane. This observation is contrary to a study which found that some P. aeruginosa biofilm cells exhibited altered morphology as a result of exposure to CT [35]. The differences in these observations corroborates the views that polyphenols from different plant sources [12] differ in their biological activity [66] at varying concentrations [67].

\subsection{Inactivation of Phage SA21RB by Phlorotannins}

Tannins can inactivate viruses by their ability to bind and interact with viral proteins [68]. The reduction in phage SA21RB titer (by $9 \log _{10}$ ) in the presence of PT corroborates that of Kulikov et al [69], where viable E. coli phage in a phage-tannins (from black tea leaves) mixture were reduced from $10^{10} \mathrm{PFU} / \mathrm{mL}$ to $10^{1} \mathrm{PFU} / \mathrm{mL}$ after exposure for $10 \mathrm{~min}$. Antiviral activity of tannins has been reported [68,70]. Although there is little information on the mechanisms of action, it is suggested that tannins can irreversibly bind to the structural proteins (capsid and adhesins) responsible for the adsorption of phage to host receptors. Therefore, it can be speculated that the reduction in SA21RB titer might have resulted from PT interacting with phage SA21RB in a manner that impedes its ability to attach to bacterial host receptors. In fact, a mixture of tea leave extracts and ferrous sulfate have been used to inactivate E. coli phages [71] and Salmonella typhimurium phage [72]. Therefore, PT would have likely impaired the ability of a phage-PT mixture to control biofilms on stainless-steel.

\section{Materials and Methods}

\subsection{Origin of Strains and Preparation}

E. coli O154:H10 is a multidrug-resistant (streptomycin, tetracycline, ampicillin, chloramphenicol, trimethoprim-sulfamethoxazole, nalidixic acid and norfloxacin) strain isolated from South African cattle feces [7] and EC20020170. O113:H21 is a Canadian STEC, of human origin, provided by Dr. Roger Johnson of the Public Health Agency of Canada (Guelph, ON). These two strains were selected based on their strong biofilm-forming abilities on polystyrene [7,73] and stainless-steel [8,74]. The strains were streaked from glycerol stocks stored at $-80^{\circ} \mathrm{C}$ onto Lysogeny broth (LB) agar (Sigma-Aldrich, Oakville, Ontario, Canada) and incubated aerobically at $37^{\circ} \mathrm{C}$ for $18 \mathrm{~h}$.

\subsection{Experiment 1}

\subsubsection{Bacteriophage Preparation and Titration}

Phage SA21RB was isolated from cattle feces in the North-West province of South Africa [39]. Phage SA21RB was chosen because it can infect and lyse E. coli O154:H10 and O113:H21 and exhibits de-polymerase activity. Phage SA21RB was propagated using E. coli O154:H10 in minimal salt (M9) broth (Sigma-Aldrich) supplemented with $0.4 \%(w / v)$ glucose, $0.02 \%(w / v) \mathrm{MgSO}_{4}$ and $0.001 \%(w / v)$ $\mathrm{CaCl}_{2}$, as described in Reference [75]. Briefly, $150 \mu \mathrm{L}$ of diluted phage stock preparation $\left(10^{9} \mathrm{PFU} / \mathrm{mL}\right)$ and $1.5 \mathrm{~mL}$ of mid-log bacterial culture were mixed and incubated for $15 \mathrm{~min}$ at $37^{\circ} \mathrm{C}$ with gentle shaking at $130 \mathrm{rpm}$. After incubation, the bacteria/phage mixture was added to $150 \mathrm{~mL}$ of M9 medium and incubated overnight at $37^{\circ} \mathrm{C}$ with shaking at $170 \mathrm{rpm}$. The overnight bacteria/phage mixture was centrifuged (Beckman Coulter, Brea, CA, USA) at $4750 \times \mathrm{g}$ for $40 \mathrm{~min}$ at $4{ }^{\circ} \mathrm{C}$ and filter sterilized using a sterile $500 \mathrm{~mL}$ disposable vacuum filtration unit $\left(0.22 \mu \mathrm{m}\right.$, Nalgene ${ }^{\circledR}$ Rapid-Flow ${ }^{\mathrm{Tm}}$ Filter, Thermo 
Scientific, West Sacramento, CA, USA). Bacteriophage titer was evaluated by the soft agar overlay plaque assay [76]. The phage SA21RB solution used in the biofilm assay contained $10^{13} \mathrm{PFU} / \mathrm{mL}$.

\subsubsection{One-Step Growth Curve}

A one-step growth curve was generated as described by Ellis and Delbrück [77]. Briefly, $100 \mu \mathrm{L}$ of phage $\left(10^{6} \mathrm{PFU} / \mathrm{mL}\right)$ was added to $900 \mu \mathrm{L}$ overnight host (O154:H10) culture and incubated for $10 \mathrm{~min}$ at $37^{\circ} \mathrm{C}$. After incubation, the phage-bacterial mixture was diluted by adding $100 \mu \mathrm{L}$ to $9.9 \mathrm{~mL}$ of LB in a $15 \mathrm{~mL}$ Falcon tube. Subsequently, $100 \mu \mathrm{L}$ of diluted phage-bacterial solution was transferred to another tube containing $9.9 \mathrm{~mL}$ of $\mathrm{LB}$ and incubated in a water bath at $37^{\circ} \mathrm{C}$. The phage-bacterial mixture was sampled $(100 \mu \mathrm{L})$ every $10 \mathrm{~min}$ over a period of $100 \mathrm{~min}$ and assessed in a plaque assay. For the plaque assay, $100 \mu \mathrm{L}$ of the phage-bacterial mixture was mixed with $3 \mathrm{~mL}$ of $0.3 \%(w / v)$ molten top agar and overlaid onto LB plates. The first sample was plated immediately (time zero) and after $15 \mathrm{~min}$ of incubation. From the 20th min of incubation, samples were plated every $10 \mathrm{~min}$. Plate counts were performed in triplicate and plotted to obtain the one-step growth curve.

\subsubsection{Microplate Phage Virulence Assay}

The susceptibility of O154:H10 and O113:H21 E. coli to phage SA21RB was determined as described by Niu et al. [44]. Briefly, $20 \mu \mathrm{L}$ of phage SA21RB was 10-fold serially diluted in $180 \mu \mathrm{L}$ M9 broth in a 96-well microplate (Nunc, Edmonton, $\mathrm{AB}$, Canada). Wells were then inoculated with $20 \mu \mathrm{L}$ of overnight cultures of $\mathrm{O} 154: \mathrm{H} 10$ and $\mathrm{O} 113: \mathrm{H} 21$ diluted 1:10 in M9. Microplates were incubated at $22{ }^{\circ} \mathrm{C}$ for $18 \mathrm{~h}$. Duplicate wells were inoculated for each bacterial strain. A negative control (wells containing M9 broth only) and a positive control (wells containing M9 broth, bacteria and no phage) were included. After incubation, phage susceptibility to bacteria was determined by visual observation of wells for turbidity as a result of bacterial growth.

\subsubsection{Biofilm Removal Using Phage SA21RB}

Biofilms were formed as described by Ma et al. [74]. For the phage treatment study, biofilms were formed on stainless-steel coupons (type 304 with number $2 \mathrm{~b}$ finish $2.54 \times 3.81 \times 0.081$, Biosurface, Bozeman, MT, USA) for 24,48 or $72 \mathrm{~h}$ at $22{ }^{\circ} \mathrm{C}$. Subsequently, the coupons were placed into a disposable sterile petri dish $(60 \times 15 \mathrm{~mm})$ containing $5 \mathrm{~mL}$ of $10^{13} \mathrm{PFU} / \mathrm{mL}$ phage suspension or M9 medium (without glucose) as a control and incubated for $3 \mathrm{~h}$ at $22^{\circ} \mathrm{C}$. After 24,48 or $72 \mathrm{~h}$, coupons with formed biofilms were placed in $25 \mathrm{~mL}$ of sterile distilled water in a $50 \mathrm{~mL}$ Falcon tube and rinsed three times in three consecutive tubes. Phage-treated and control coupons were placed in $25 \mathrm{~mL}$ of sterile $10 \mathrm{mM}$ phosphate buffered saline (PBS, pH 7.4), and sonicated at $20 \mathrm{kHz}$ for $10 \mathrm{~min}$, followed by vortexing for $1 \mathrm{~min}$. An aliquot $(2 \mathrm{~mL})$ of the suspension was placed in an Eppendorf tube and centrifuged for $3 \mathrm{~min}$ at $13,000 \times \mathrm{g}$ to separate unabsorbed phage from bacteria. The supernatant was discarded, and bacteria were resuspended in $1 \mathrm{~mL}$ of sterile PBS. Bacterial suspension was 10-fold serially diluted, plated on LB agar, and incubated at $37^{\circ} \mathrm{C}$ for $18 \mathrm{~h}$. To verify the action of phage SA21RB on preformed biofilms, plate counts of phage-treated bacteria strains were compared with those of a positive control. The results were expressed as the average of the data from two independent assays.

\subsection{Experiment 2}

\subsubsection{Isolation of Condensed Tannins and Phlorotannins}

Condensed tannins and phlorotannins were extracted from purple prairie clover (Dalea purpurea) grown at Lethbridge, AB, Canada, and brown seaweed (Ascophyllum nodosum) was harvested from the Atlantic coast of Nova Scotia, Canada (Acadian Seaplants Limited, Dartmouth, NS, USA). Samples were extracted with acetone, water and ascorbic acid (7:3:1), as described by Wang et al. [31]. Specifically, $500 \mathrm{~g}$ of ground samples were mixed in extraction solvent $(70 \%$ aqueous acetone $v / v)$ and stirred for $1 \mathrm{~h}$ at room temperature $\left(22{ }^{\circ} \mathrm{C}\right)$. Samples were filtered through a monofilament polyester $335 \mu \mathrm{m}$ 
filter and the filtrate was mixed with an equal volume of diethyl ether to achieve phase separation. The supernatant was aspirated using a Speed Vac water jet (Savant Instruments, Inc. Farmingdale, New York, NY, USA). The aqueous phase was centrifuged $\left(20 \mathrm{~min} ; 5000 \times g ; 4{ }^{\circ} \mathrm{C}\right)$ and filtrates were rotary evaporated under vacuum at $40{ }^{\circ} \mathrm{C}$ to remove acetone and ether. The remaining aqueous residue (crude tannin) was freeze-dried. The freeze-dried powder of condensed tannins (CT) and phlorotannins (PT) were further processed to isolate tannins, as described by Wang et al. [31]. Briefly, dried crude tannin extracts were dissolved in $80 \%(v / v)$ ethanol. The mixture was stirred for $1 \mathrm{~h}$ at room temperature $\left(22{ }^{\circ} \mathrm{C}\right)$ and filtered through an EMD Millipore Glass Vacuum Filter Holder. Filtrate was added to a Sephadex ${ }^{\mathrm{TM}}$ LH-20 (Sigma-Aldrich) slurry equilibrated with $80 \%(v / v)$ ethanol. The tannin-Sephadex mixture was left for $45 \mathrm{~min}$ at room temperature to enable tannins to bind to the Sephadex beads. The tannin-Sephadex mixture was filtered using an EMD Millipore Glass Vacuum Filter Holder to remove non-tannin materials. Subsequent washes were performed on tannin-Sephadex with $4750 \mathrm{~mL}$ of $80 \%(v / v)$ ethanol until the elute was clear. Thereafter, tannins were eluted from the beads using $2000 \mathrm{~mL}$ of $50 \%$ acetone. The aqueous acetone-tannin elution was rotary evaporated under vacuum at $40{ }^{\circ} \mathrm{C}$ to remove acetone. Purified extracts were freeze-dried and stored at $-20^{\circ} \mathrm{C}$ in an amber bottle until used.

\subsubsection{Effects of Condensed Tannins (CT) and Phlorotannins (PT) on Growth of O154:H10 and O113:H21 E. coli}

The two tannin extracts were dissolved separately in sterile M9 medium supplemented with $0.4 \%$ $(w / v)$ glucose, $0.02 \%(w / v) \mathrm{MgSO}_{4}$ and $0.001 \%(w / v) \mathrm{CaCl}_{2}$ to obtain a concentration of $400 \mu \mathrm{g} / \mathrm{mL}$. Two-fold dilutions of both the CT and PT were obtained in accordance with Wang et al. [31], generating tannin concentrations of 400,200,100,50 and $25 \mu \mathrm{g} / \mathrm{mL}$ that were used to assess the minimum inhibitory concentration (MIC) of the extracts. Overnight bacterial culture of O154:H10 and O113:H21 E. coli were diluted (1:10) with M9 medium to achieve a final concentration of 7 log CFU/mL. Bacterial inoculum $(50 \mu \mathrm{L})$ was added to each well within a 96-well microplate (Nunc, Edmonton, AB, Canada) containing $150 \mu \mathrm{L}$ of the different concentrations of either CT or PT. Triplicate wells were inoculated for each bacterial strain. Negative (wells containing tannin, M9 and no bacteria) and positive controls (wells with M9, bacteria and no tannin) were included. Wells with tannin and M9 medium only were used as blank controls. Plates were incubated aerobically without shaking for $24 \mathrm{~h}$ at $22{ }^{\circ} \mathrm{C}$ and growth was determined by measuring the optical density at $600 \mathrm{~nm}$ using an enzyme-linked immunosorbent assay (ELISA) plate reader (Synergy ${ }^{\text {TM }}$ HT BioTek, Highland Park, Winooski, VT, USA). To determine the minimum bactericidal concentration (MBC), $100 \mu \mathrm{L}$ of varying concentrations $(400,200,100,50$ and $25 \mu \mathrm{g} / \mathrm{mL}$ ) were used in the MIC assay and control wells without tannins were 10-fold serially diluted and plated on LB agar and incubated at $37^{\circ} \mathrm{C}$ for $18 \mathrm{~h}$ to enumerate colonies.

\subsubsection{Anti-Biofilm Assay of Phlorotannins on Stainless Coupons}

Biofilm formation potential of the isolates was assessed as described by Ma et al. [74]. Compared to PT, CT exhibited a weak inhibitory effect at concentration $25-400 \mu \mathrm{g} / \mathrm{mL}$ on planktonic cells of O154:H10 and O113:H21. Consequently, the anti-biofilm activity of PT at the lowest concentration $(50 \mu \mathrm{g} / \mathrm{mL})$ exhibiting bacteriostatic activity against O154:H10 and O113:H21 was further evaluated. The same stainless-steel coupons as described above were used for anti-biofilm analyses. Specifically, PT was diluted in M9 medium to achieve a final concentration of $50 \mu \mathrm{g} / \mathrm{mL}$. Thereafter, overnight STEC cultures were diluted in PT-M9 medium to achieve a final concentration of $7 \log$ CFU/mL, coupon immersed into $50 \mathrm{~mL}$ Falcon tubes and incubated for biofilm formation, as described by Ma et al. [41]. In the biofilm formation assay, M9 medium without PT was used as a positive control. Data were acquired from two independent experiments conducted in triplicates. 


\subsubsection{Enumeration of the Planktonic and Adhered Bacterial Cells after Anti-Biofilm Assay}

Planktonic cells after each period were enumerated according to Bumunang et al. [8]. Briefly, $1 \mathrm{~mL}$ of the cell suspension was pipetted from the Falcon tube (with and without tannin treatment), ten-fold serially diluted with $10 \mathrm{mM}$ PBS (pH 7.4), plated on LB agar and incubated aerobically at $37^{\circ} \mathrm{C}$ for $18 \mathrm{~h}$. Subsequently, the colony-forming units $(\mathrm{CFU} / \mathrm{mL})$ were determined for each plate from two independent experiments. Biofilm cells on coupons (with and without tannin treatment) were removed according to Bumunang et al. [8]. Briefly, coupons were rinsed three times with sterile water, immersed in $25 \mathrm{~mL}$ of sterile PBS and sonicated at $20 \mathrm{kHz}$ for $10 \mathrm{~min}$, followed by vortexing for $1 \mathrm{~min}$. The same procedure as above was used to enumerate biofilm cells.

\subsection{Scanning Electron Microscopy (SEM) Analysis}

Phage-treated and control coupons, as well as tannin-treated and control coupons, were prepared as described by Ma et al. [41], and biofilm cells were examined by scanning electron microscopy according to Arnold and Bailey [78]. Briefly, treated (phage or tannin) and untreated coupons were fixed in $2.5 \%(v / v)$ glutaraldehyde overnight following a series of ethanol dehydration at $10 \%, 30 \%$, $50 \%, 70 \%, 90 \%$ and $100 \%$, and isobutyl alcohol dilutions (v/v) (i.e., $10 \%, 30 \%, 50 \%, 70 \%, 90 \%$ and $100 \%$ ). The coupons were then dried in $100 \%(v / v)$ hexamethyldisilazane for $10 \mathrm{~min}$ and observed with a scanning electron microscope (HITACHI S-4800, Tokyo, Japan).

\subsection{Experiment 3}

Virucidal Action of Phlorotannins against Phage SA21RB

The virucidal property of phlorotannins against phage SA21RB was tested as described by Kulikov et al. [69], with some modifications. Briefly, PT were prepared according to Wang et al. [31], and $1 \mathrm{~mL}$ of phage stock $\left(10^{13} \mathrm{PFU} / \mathrm{mL}\right)$ was added to $1 \mathrm{~mL}$ of phlorotannins $(100 \mu \mathrm{g} / \mathrm{mL})$ to achieve a final concentration of $50 \mu \mathrm{g} / \mathrm{mL}$. Equally, $1 \mathrm{~mL}$ of phage stock was added to $1 \mathrm{~mL}$ of M9 broth (PT-free) to serve as a control. Phage-PT mixture was incubated at $22^{\circ} \mathrm{C}$ for $3 \mathrm{~h}$, conditions similar to those used in the phage SA21RB biofilm removal study. After incubation, aliquots of the phage-PT mixtures $(100 \mu \mathrm{L})$ were used for a plaque assay using the soft agar overlay technique [76] to enumerate viable phages. Controls included a mixture of mid-log phase bacteria (O154:H10; host strain) with phage only, without PT, and a mixture of bacteria and M9 only (no phage and PT). Assays were performed in triplicate.

\subsection{Statistical Analysis}

Experiments one and two were independently performed two times with three replicates for phage-treated and non-treated samples, as well as tannin-treated and control samples, according to Bumunang et al. [8]. Data were reported as the average and standard deviation within each triplicate. Difference in treated and untreated samples were determined using the least squares means and two-way analysis of variance (ANOVA) in the Statistical Analysis System (SAS 8.01, SAS Institute, Cary, NC, USA). Statistical significance was presented at $p \leq 0.05$ and means were separated using the general linear models' procedure.

\section{Conclusions}

Populations of biofilm cells on stainless-steel coupon were reduced by phage SA21RB, with this response being more apparent for biofilms that formed over $24 \mathrm{~h}$ as compared to $72 \mathrm{~h}$. Phage did not completely remove biofilm cells, although we assumed that the use of a depolymerase-producing phage would increase the extent of biofilm removal. Further studies by either applying phage SA21RB as a cocktail with other phages or in synergy with antimicrobials may be needed to enhance activity against STEC biofilms. Phlorotannins prevented biofilm formation for up to $24 \mathrm{~h}$, although this efficacy decreased with longer incubation times. Treatment of stainless-steel surfaces with PT 
every $24 \mathrm{~h}$ could be one approach to reducing the formation of STEC biofilms on stainless-steel in food-processing environments.

Supplementary Materials: The following are available online at http://www.mdpi.com/2079-6382/9/5/257/s1: Figure S1: Effect of phlorotannin (PT; $50 \mu \mathrm{g} / \mathrm{mL}$ ) on phage SA21RB using soft agar overlay technique. Bacteria only (no phage and PT (A)); bacteria, phage and PT (dilution 1 (B)); bacteria, phage and PT (dilution 8 (C)); soft agar only (no bacteria, phage and PT (D)); bacteria and phage only (no PT dilution 1 (E)) and bacteria and phage only (no PT dilution $8(\mathrm{~F})$ ).

Author Contributions: Conceptualization, C.N.A., K.S., Y.D.N., Y.W. and T.A.M.; methodology, C.N.A., K.S., Y.D.N., Y.W., E.W.B. and T.A.M.; software, T.A.M., K.S., Y.D.N., Y.W., E.W.B. and C.N.A.; validation, T.A.M., K.S., Y.D.N., Y.W., E.W.B., and C.N.A.; formal analysis, E.W.B. and Y.W.; investigation, E.W.B. and Y.W.; resources, C.N.A., K.S., Y.D.N., Y.W. and T.A.M.; writing-original draft preparation, E.W.B.; writing-review and editing, C.N.A., K.S., Y.D.N., E.W.B., Y.W. and T.A.M.; supervision, C.N.A., K.S., Y.D.N., Y.W. and. T.A.M.; project administration, C.N.A., K.S., Y.D.N., Y.W. and T.A.M.; funding acquisition, C.N.A., K.S. and T.A.M. All authors have read and agreed to the published version of the manuscript.

Funding: This work is based on research supported in part by the National Research Foundation of South Africa (Grant UID Number 98983), together with North-West University research funds. Growing Forward II (GF2) of Alberta Agriculture and Forestry, CAP Accelerating the Advancement of Agriculture Innovation Program of Alberta Agriculture and Forestry, and the Agriculture and Agri-Food Canada-Beef Cluster program, grant FOS.07.17.

Acknowledgments: We acknowledge the technical assistance of R. Ha, C. Conrad, R. Barbieri, S. Trapp and Y. Graham during the study.

Conflicts of Interest: The authors declare no conflicts of interest.

\section{References}

1. Hussain, M.A.; Dawson, C.O. Economic impact of food safety outbreaks on food businesses. Foods 2013, 2, 585-589. [CrossRef]

2. Beutin, L.; Martin, A. Outbreak of Shiga toxin-producing Escherichia coli (STEC) O104:H4 infection in Germany causes a paradigm shift with regard to human pathogenicity of STEC strains. J. Food Prot. 2012, 75, 408-418. [CrossRef]

3. Mikhail, A.; Jenkins, C.; Dallman, T.; Inns, T.; Douglas, A.; Martín, A.; Fox, A.; Cleary, P.; Elson, R.; Hawker, J. An outbreak of Shiga toxin-producing Escherichia coli O157:H7 associated with contaminated salad leaves: Epidemiological, genomic and food trace back investigations. Epidemiol. Infect. 2018, 146, 187-196. [CrossRef]

4. Wilson, D.; Dolan, G.; Aird, H.; Sorrell, S.; Dallman, T.J.; Jenkins, C.; Robertson, L.; Gorton, R. Farm-to-fork investigation of an outbreak of Shiga toxin-producing. Escherichia coli O157. Microb. Genom. 2018, 4, 1-7. [CrossRef] [PubMed]

5. Karmali, M.A.; Mascarenhas, M.; Shen, S.; Ziebell, K.; Johnson, S.; Reid-Smith, R.; Isaac-Renton, J.; Clark, C.; Rahn, K.; Kaper, J.B. Association of genomic O island 122 of Escherichia coli EDL 933 with verocytotoxin-producing Escherichia coli seropathotypes that are linked to epidemic and/or serious disease. J. Clin. Microbiol. 2003, 41, 4930-4940. [CrossRef] [PubMed]

6. Feng, P.C.; Delannoy, S.; Lacher, D.W.; dos Santos, L.F.; Beutin, L.; Fach, P.; Rivas, M.; Hartland, E.L.; Paton, A.W.; Guth, B.E. Genetic diversity and virulence potential of Shiga toxin-producing Escherichia coli O113:H21 strains isolated from clinical, environmental, and food sources. Appl. Environ. Microbiol. 2014, 80, 4757-4763. [CrossRef] [PubMed]

7. Bumunang, E.W.; McAllister, T.A.; King, R.; Ortega Polo, R.; Stanford, K.; Zaheer, R.; Niu, Y.D.; Ateba, C.N. Characterization of Non-O157 Escherichia coli from Cattle Faecal Samples in the North-West Province of South Africa. Microorganisms 2019, 7, 272. [CrossRef] [PubMed]

8. Bumunang, E.W.; Ateba, C.; Stanford, K.; McAllister, T.A.; Niu, Y.D. Biofilm formation by South-African Shiga toxigenic non-O157 Escherichia coli on stainless steel coupons. Can. J. Microbiol. 2020, 66, 328-336. [CrossRef]

9. Wang, R. Biofilms and meat safety: A mini-review. J. Food Prot. 2018, 82, 120-127. [CrossRef]

10. Galie, S.; García-Gutiérrez, C.; Miguélez, E.M.; Villar, C.J.; Lombó, F. Biofilms in the food industry: Health aspects and control methods. Front. Microbiol. 2018, 9, 1-18. [CrossRef] 
11. Flemming, H.-C.; Wingender, J.; Szewzyk, U.; Steinberg, P.; Rice, S.A.; Kjelleberg, S. Biofilms: An emergent form of bacterial life. Nat. Rev. Microbiol. 2016, 14, 563-575. [CrossRef]

12. Lahiri, D.; Dash, S.; Dutta, R.; Nag, M. Elucidating the effect of anti-biofilm activity of bioactive compounds extracted from plants. J. Biosci. 2019, 44, 1-19. [CrossRef]

13. Mulcahy, H.; Charron-Mazenod, L.; Lewenza, S. Extracellular DNA chelates cations and induces antibiotic resistance in Pseudomonas aeruginosa biofilms. PLoS Pathog. 2008, 4, 1-12. [CrossRef] [PubMed]

14. Hall, C.W.; Mah, T.-F. Molecular mechanisms of biofilm-based antibiotic resistance and tolerance in pathogenic bacteria. FEMS Microbiol. Rev. 2017, 41, 276-301. [CrossRef] [PubMed]

15. Koo, H.; Allan, R.N.; Howlin, R.P.; Stoodley, P.; Hall-Stoodley, L. Targeting microbial biofilms: Current and prospective therapeutic strategies. Nat. Rev. Microbiol. 2017, 15, 740-755. [CrossRef] [PubMed]

16. Chmielewski, R.; Frank, J. Biofilm formation and control in food processing facilities. Compr. Rev. Food Sci. 2003, 2, 22-32. [CrossRef]

17. Bayoumi, M.A.; Kamal, R.M.; El Aal, S.F.A.; Awad, E.I. Assessment of a regulatory sanitization process in Egyptian dairy plants in regard to the adherence of some food-borne pathogens and their biofilms. Int. J. Food Microbiol. 2012, 158, 225-231. [CrossRef]

18. Singh, S.; Singh, S.K.; Chowdhury, I.; Singh, R. Understanding the mechanism of bacterial biofilms resistance to antimicrobial agents. Open Microbiol. J. 2017, 11, 53-62. [CrossRef]

19. Falowo, A.B.; Akimoladun, O.F. Veterinary Drug Residues in Meat and Meat Products: Occurrence, Detection and Implications: Veterinary Pharmaceuticals. IntechOpen 2019, 1-18.

20. Joerger, R. Alternatives to antibiotics: Bacteriocins, antimicrobial peptides and bacteriophages. Poult Sci. 2003, 82, 640-647. [CrossRef]

21. Hagens, S.; Loessner, M.J. Bacteriophage for biocontrol of foodborne pathogens: Calculations and considerations. Curr. Pharm. Biotechnol. 2010, 11, 58-68. [CrossRef] [PubMed]

22. Drulis-Kawa, Z.; Majkowska-Skrobek, G.; Maciejewska, B.; Delattre, A.-S.; Lavigne, R. Learning from bacteriophages-advantages and limitations of phage and phage-encoded protein applications. Curr. Protein Pept. Sci. 2012, 13, 699-722. [CrossRef] [PubMed]

23. Chan, B.K.; Abedon, S.T. Bacteriophages and their enzymes in biofilm control. Curr. Pharm. Des. 2015, 21, 85-99. [CrossRef] [PubMed]

24. Sharma, M.; Ryu, J.H.; Beuchat, L. Inactivation of Escherichia coli O157:H7 in biofilm on stainless steel by treatment with an alkaline cleaner and a bacteriophage. J. Appl. Microbiol. 2005, 99, 449-459. [CrossRef]

25. Chibeu, A.; Lingohr, E.J.; Masson, L.; Manges, A.; Harel, J.; Ackermann, H.-W.; Kropinski, A.M.; Boerlin, P. Bacteriophages with the ability to degrade uropathogenic Escherichia coli biofilms. Viruses 2012, 4, 471-487. [CrossRef]

26. Arachchi, G.J.G.; Cridge, A.G.; Dias-Wanigasekera, B.M.; Cruz, C.D.; McIntyre, L.; Liu, R.; Flint, S.H.; Mutukumira, A.N. Effectiveness of phages in the decontamination of Listeria monocytogenes adhered to clean stainless steel, stainless steel coated with fish protein, and as a biofilm. J. Ind. Microbiol. 2013, 40, 1105-1116.

27. Abedon, S. Ecology of anti-biofilm agents II: Bacteriophage exploitation and biocontrol of biofilm bacteria. Pharmaceuticals 2015, 8, 559-589. [CrossRef]

28. Gutiérrez, D.; Rodríguez-Rubio, L.; Martínez, B.; Rodríguez, A.; García, P. Bacteriophages as weapons against bacterial biofilms in the food industry. Front. Microbiol. 2016, 7, 1-15. [CrossRef]

29. Slobodníková, L.; Fialová, S.; Rendeková, K.; Kováč, J.; Mučaji, P. Antibiofilm activity of plant polyphenols. Molecules 2016, 21, 1717. [CrossRef]

30. Khatoon, Z.; McTiernan, C.D.; Suuronen, E.J.; Mah, T.-F.; Alarcon, E.I. Bacterial biofilm formation on implantable devices and approaches to its treatment and prevention. Heliyon 2018, 4, 1-36. [CrossRef]

31. Wang, Y.; Xu, Z.; Bach, S.; McAllister, T. Sensitivity of Escherichia coli to seaweed (Ascophyllum nodosum) phlorotannins and terrestrial tannins. Asian-Australas. J. Anim. Sci. 2009, 22, 238-245. [CrossRef]

32. Olajuyigbe, O.; Afolayan, A. In vitro antibacterial activities of crude aqueous and ethanolic extracts of the stem bark of Acacia mearnsii De Wild. Afr. J. Pharm. 2011, 5, 1234-1240. [CrossRef]

33. Wang, Y.; Jin, L.; Ominski, K.H.; He, M.; Xu, Z.; Krause, D.O.; Acharya, S.N.; Wittenberg, K.M.; Liu, X.L.; Stanford, K.; et al. Screening of condensed tannins from Canadian prairie forages for anti-Escherichia coli O157:H7 with an emphasis on purple prairie clover (Dalea purpurea Vent). J. Food Prot. 2013, 76, 560-567. [CrossRef] [PubMed] 
34. Koczan, J.M.; Lenneman, B.R.; McGrath, M.J.; Sundin, G.W. Cell surface attachment structures contribute to biofilm formation and xylem colonization by Erwinia amylovora. Appl. Environ. Microbiol. 2011, 77, 7031-7039. [CrossRef]

35. Trentin, D.S.; Silva, D.B.; Amaral, M.W.; Zimmer, K.R.; Silva, M.V.; Lopes, N.P.; Giordani, R.B.; Macedo, A.J. Tannins possessing bacteriostatic effect impair Pseudomonas aeruginosa adhesion and biofilm formation. PLoS ONE 2013, 8, 1-13. [CrossRef] [PubMed]

36. Song, Y.J.; Yu, H.H.; Kim, Y.J.; Lee, N.-K.; Paik, H.-D. Anti-Biofilm Activity of Grapefruit Seed Extract against Staphylococcus aureus and Escherichia coli. J. Microbiol. Biotechnol. 2019, 29, 1177-1183. [CrossRef] [PubMed]

37. Bennick, A. Interaction of plant polyphenols with salivary proteins. Crit. Rev. Oral Biol. Med. 2002, 13, 184-196. [CrossRef]

38. Paengkoum, P.; Phonmun, T.; Liang, J.; Huang, X.; Tan, H.; Jahromi, M. Molecular Weight, Protein Binding Affinity and Methane Mitigation of Condensed Tannins from Mangosteen-peel (Garcinia mangostana L). Asian-Australas. J. Anim. Sci. 2015, 28, 1442-1448. [CrossRef]

39. Bumunang, E.W.; McAllister, T.A.; Stanford, K.; Anany, H.; Niu, Y.D.; Ateba, C.N. Characterization of Non-O157 STEC Infecting Bacteriophages Isolated from Cattle Faeces in North-West South Africa. Microorganisms 2019, 7, 615. [CrossRef]

40. Kokare, C.; Chakraborty, S.; Khopade, A.; Mahadik, K.R. Biofilm: Importance and applications. Indian J. Biotechnol. 2009, 8, 159-168.

41. Davies, D. Understanding biofilm resistance to antibacterial agents. Nat. Rev. Drug Discov. 2003, 2, 114-122. [CrossRef] [PubMed]

42. Gopal, N.; Hill, C.; Ross, P.R.; Beresford, T.P.; Fenelon, M.A.; Cotter, P.D. The prevalence and control of Bacillus and related spore-forming bacteria in the dairy industry. Front. Microbiol. 2015, 6, 1-18. [CrossRef] [PubMed]

43. Holmfeldt, K.; Middelboe, M.; Nybroe, O.; Riemann, L. Large variabilities in host strain susceptibility and phage host range govern interactions between lytic marine phages and their Flavobacterium hosts. Appl. Environ. Microbiol. 2007, 73, 6730-6739. [CrossRef] [PubMed]

44. Niu, Y.D.; Johnson, R.P.; Xu, Y.; McAllister, T.A.; Sharma, R.; Louie, M.; Stanford, K. Host range and lytic capability of four bacteriophages against bovine and clinical human isolates of Shiga toxin-producing Escherichia coli O157:H. J. Appl. Microbiol. 2009, 107, 646-656. [CrossRef] [PubMed]

45. Stone, E.; Campbell, K.; Grant, I.; McAuliffe, O. Understanding and exploiting phage-Host interactions. Viruses 2019, 11, 567. [CrossRef]

46. Sadekuzzaman, M.; Yang, S.; Mizan, M.F.R.; Ha, S.D. Reduction of Escherichia coli O157:H7 in biofilms using bacteriophage BPECO. J. Food Sci. 2017, 82, 1433-1442. [CrossRef] [PubMed]

47. Soni, K.A.; Nannapaneni, R. Removal of Listeria monocytogenes biofilms with bacteriophage P100. J. Food Prot. 2010, 73, 1519-1524. [CrossRef]

48. Sillankorva, S.; Neubauer, P.; Azeredo, J. Pseudomonas fluorescens biofilms subjected to phage phiIBB-PF7A. BMC Biotechnol. 2008, 8, 1-12. [CrossRef]

49. Sillankorva, S.; Oliveira, R.; Vieira, M.J.; Sutherland, I.; Azeredo, J. Pseudomonas fluorescens infection by bacteriophage $\Phi S 1$ : The influence of temperature, host growth phase and media. FEMS Microbiol. Lett. 2004, 241, 13-20. [CrossRef]

50. Sillankorva, S.; Neubauer, P.; Azeredo, J. Phage control of dual species biofilms of Pseudomonas fluorescens and Staphylococcus lentus. Biofouling 2010, 26, 567-575. [CrossRef]

51. Sutherland, I.W.; Hughes, K.A.; Skillman, L.C.; Tait, K. The interaction of phage and biofilms. FEMS Microbiol. Lett. 2004, 232, 1-6. [CrossRef]

52. Łoś, M.; Golec, P.; Łoś, J.M.; Węglewska-Jurkiewicz, A.; Czyż, A.; Węgrzyn, A.; Węgrzyn, G.; Neubauer, P. Effective inhibition of lytic development of bacteriophages $\lambda, \mathrm{P} 1$ and T4 by starvation of their host, Escherichia coli. BMC Biotechnol. 2007, 7, 1-6. [CrossRef] [PubMed]

53. Abedon, S.T. Bacteriophage exploitation of bacterial biofilms: Phage preference for less mature targets? FEMS Microbiol. Lett. 2016, 363, 1-5. [CrossRef]

54. Harper, D.R.; Parracho, H.M.; Walker, J.; Sharp, R.; Hughes, G.; Werthén, M.; Lehman, S.; Morales, S. Bacteriophages and biofilms. Antibiotics 2014, 3, 270-284. [CrossRef]

55. Yan, J.; Mao, J.; Xie, J. Bacteriophage polysaccharide depolymerases and biomedical applications. BioDrugs 2014, 28, 265-274. [CrossRef] 
56. Nagayama, K.; Iwamura, Y.; Shibata, T.; Hirayama, I.; Nakamura, T. Bactericidal activity of phlorotannins from the brown alga Ecklonia kurome. J. Antimicrob. Chemother. 2002, 50, 889-893. [CrossRef]

57. Pérez, M.J.; Falqué, E.; Domínguez, H. Antimicrobial action of compounds from marine seaweed. Mar. Drugs 2016, 14, 1-38.

58. Okuda, T.; Ito, H. Tannins of constant structure in medicinal and food plants-Hydrolyzable tannins and polyphenols related to tannins. Molecules 2011, 16, 2191-2217. [CrossRef]

59. Da Silva Trentin, D.; Giordani, R.B.; Zimmer, K.R.; Da Silva, A.G.; Da Silva, M.V.; dos Santos Correia, M.T.; Baumvol, I.J.R.; Macedo, A.J. Potential of medicinal plants from the Brazilian semi-arid region (Caatinga) against Staphylococcus epidermidis planktonic and biofilm lifestyles. J. Ethnopharmacol. 2011, 137, 327-335. [CrossRef] [PubMed]

60. Lu, L.; Hu, W.; Tian, Z.; Yuan, D.; Yi, G.; Zhou, Y.; Cheng, Q.; Zhu, J.; Li, M. Developing natural products as potential anti-biofilm agents. Chin. Med. 2019, 14,1-14. [CrossRef]

61. Moraes, J.O.; Cruz, E.A.; Souza, E.G.; Oliveira, T.C.; Alvarenga, V.O.; Peña, W.E.; Sant'Ana, A.S.; Magnani, M. Predicting adhesion and biofilm formation boundaries on stainless steel surfaces by five Salmonella enterica strains belonging to different serovars as a function of $\mathrm{pH}$, temperature and $\mathrm{NaCl}$ concentration. Int. J. Food Microbiol. 2018, 281, 90-100. [CrossRef] [PubMed]

62. Makkar, H.; Becker, K. Effect of $\mathrm{pH}$, temperature, and time on inactivation of tannins and possible implications in detannification studies. J. Agric. Food Chem. 1996, 44, 1291-1295. [CrossRef]

63. Ford, L.; Theodoridou, K.; Sheldrake, G.N.; Walsh, P.J. A critical review of analytical methods used for the chemical characterisation and quantification of phlorotannin compounds in brown seaweeds. Phytochem. Anal. 2019, 30, 587-599. [CrossRef] [PubMed]

64. Imbs, T.; Zvyagintseva, T. Phlorotannins are polyphenolic metabolites of brown algae. Russ. J. Mar. Biol. 2018, 44, 263-273. [CrossRef]

65. Davey, M.E.; O'toole, G.A. Microbial biofilms: From ecology to molecular genetics. Microbiol. Mol. Biol. Rev. 2000, 64, 847-867. [CrossRef]

66. McAllister, T.A.; Martinez, T.; Bae, H.D.; Muir, A.D.; Yanke, L.J.; Jones, G.A. Characterization of condensed tannins purified from legume forages: Chromophore production, protein precipitation, and inhibitory effects on cellulose digestion. J. Chem. Ecol. 2005, 31, 2049-2068. [CrossRef]

67. Li, Y.; Iwaasa, A.; Wang, Y.; Jin, L.; Han, G.; Zhao, M. Condensed tannins concentration of selected prairie legume forages as affected by phenological stages during two consecutive growth seasons in western Canada. Can. J. Plant Sci. 2014, 94, 817-826. [CrossRef]

68. Vilhelmova-Ilieva, N.; Galabov, A.S.; Mileva, M. Tannins as Antiviral Agents, Tannins-Structural Properties, Biological Properties and Current Knowledge. IntechOpen 2019, 1-14.

69. Kulikov, E.E.; Golomidova, A.K.; Letarova, M.A.; Kostryukova, E.S.; Zelenin, A.S.; Prokhorov, N.S.; Letarov, A.V. Genomic sequencing and biological characteristics of a novel Escherichia coli bacteriophage $9 \mathrm{~g}$, a putative representative of a new Siphoviridae genus. Viruses 2014, 6, 5077-5092. [CrossRef]

70. Theisen, L.L.; Erdelmeier, C.A.; Spoden, G.A.; Boukhallouk, F.; Sausy, A.; Florin, L.; Muller, C.P. Tannins from Hamamelis virginiana bark extract: Characterization and improvement of the antiviral efficacy against influenza A virus and human papillomavirus. PLoS ONE 2014, 9, e88062. [CrossRef]

71. Liu, H.; Meng, R.; Wang, J.; Niu, Y.D.; Li, J.; Stanford, K.; McAllister, T. Inactivation of Escherichia coli O157 bacteriophages by using a mixture of ferrous sulfate and tea extract. J. Food Prot. 2015, 78, 2220-2226. [CrossRef] [PubMed]

72. De Siqueira, R.; Dodd, C.; Rees, C. Evaluation of the natural virucidal activity of teas for use in the phage amplification assay. Int. J. Food Microbiol. 2006, 111, 259-262. [CrossRef] [PubMed]

73. Wang, J.; Stanford, K.; McAllister, T.A.; Johnson, R.P.; Chen, J.; Hou, H.; Zhang, G.; Niu, Y.D. Biofilm Formation, Virulence Gene Profiles, and Antimicrobial Resistance of Nine Serogroups of Non-O157 Shiga Toxin-Producing Escherichia coli. Foodborne Pathog. Dis. 2016, 13, 316-324. [CrossRef] [PubMed]

74. Ma, Z.; Bumunang, E.W.; Stanford, K.; Bie, X.; Niu, Y.D.; McAllister, T.A. Biofilm Formation by Shiga Toxin-Producing Escherichia coli on Stainless Steel Coupons as Affected by Temperature and Incubation Time. Microorganisms 2019, 7, 95. [CrossRef] [PubMed]

75. Niu, Y.D.; Stanford, K.; McAllister, T.A.; Ackermann, H.-W. Characterization of 4 T1-like lytic bacteriophages that lyse Shiga-toxin Escherichia coli O157:H7. Can. J. Microbiol. 2012, 58, 923-927. [CrossRef] [PubMed] 
76. Sambrook, J.; Russell, D. Molecular Cloning: A Laboratory Manual, 3rd ed.; Cold Spring Harbor: New York, NY, USA, 2001.

77. Ellis, E.L.; Delbrück, M. The growth of bacteriophage. J. Gen. Physiol. 1939, 22, 365-384. [CrossRef]

78. Arnold, J.; Bailey, G. Surface finishes on stainless steel reduce bacterial attachment and early biofilm formation: Scanning electron and atomic force microscopy study. Poult. Sci. 2000, 79, 1839-1845. [CrossRef]

(c) (1)

(C) 2020 by the authors. Licensee MDPI, Basel, Switzerland. This article is an open access article distributed under the terms and conditions of the Creative Commons Attribution (CC BY) license (http://creativecommons.org/licenses/by/4.0/). 